\title{
HUBUNGAN WILAYAH KERJA TERHADAP KEJADIAN JAMUR PADA KARYAWAN PT.PERKEBUNAN NUSANTARA VII
}

\author{
Lely Suryaningsih, Susiwati \\ Politeknik Kesehatan Kementerian Kesehatan Bengkulu, Jurusan Analis Kesehatan, \\ Jalan Indragiri Nomor 03 Padang Harapan Kota Bengkulu \\ susi7925@yahoo.com
}

\begin{abstract}
Dermatophytosis was a disease in tissues that contain substances on the horn for example stratum corneum epidermidis, hair and nails caused by dermatophyte fungi group. Dermatophytosis had keratinofilik nature, each species of dermatophytes had an affinity for a particular host. Zoophilic dermatophytes which primarily affects animals, and humans. This study aimed to determine the relationship of the working area on the incidence of fungal infections of the employees of PT. Plantation Nusantara VII in North Bengkulu. This research was observational analytic cross-sectional design, the independent variable was the area of employment, the dependent variable was the incidence of fungal infections. The population was 29 employees PT. Perkebunan Nusantara VII, samples of all employees PT.Perkebunan Nusantara VII with a total sampling technique. Data was analyzed using frequency distribution and bivariate using Chi-Square test. The results revealed that the majority of employees working in the processing of fungal infection that is equal to $88.2 \%$, which was statistically significant relationship between the working area with the incidence of fungal infections. Director PT.Perkebunan Nusantara VII should pay more attention to the safety of its employees with a firmer giving rules and providing extension ignore the dangers of the use of personal protective equipment can cause fungal infections.
\end{abstract}

Keywords: Dermatophytosis, working area

\begin{abstract}
Abstrak : Dermatofitosis adalah penyakit pada jaringan yang mengandung zat tanduk misalnya stratum korneum pada epidermidis, rambut dan kuku yang disebabkan oleh golongan jamur dermatofita. Dermatofitosis mempunyai sifat keratinofilik, setiap spesies dermatofita mempunyai afinitas terhadap hospes tertentu. Dermatofita yang zoofilik terutama menyerang binatang, dan manusia. Penelitian ini bertujuan untuk mengetahui hubungan wilayah kerja terhadap kejadian infeksi jamur pada karyawan PT. Perkebunan Nusantara VII di Kabupaten Bengkulu Utara. Penelitian ini merupakan penelitian observasional analitik dengan desain cross sectional, variabel independen adalah wilayah kerja karyawan, variabel dependen adalah kejadian infeksi jamur. Populasi adalah 29 orang karyawan PT.Perkebunan Nusantara VII, sampel semua karyawan PT.Perkebunan Nusantara VII dengan teknik total sampling. Analisis data dilakukan dengan distribusi frekuensi dan bivariat dengan menggunakan uji Chi-Square. Hasil penelitian diketahui bahwa sebagian besar karyawan yang bekerja di bagian pengolahan terinfeksi jamur yaitu sebesar $88,2 \%$ yang secara statistik ada hubungan yang signifikan antara wilayah kerja dengan kejadian infeksi jamur. Direktur PT.Perkebunan Nusantara VII hendaknya lebih memperhatikan keselamatan para karyawannya dengan lebih tegas memberi peraturan dan mengadakan penyuluhan bahaya mengabaikan pemakaian alat pelindung diri yang dapat menyebabkan infeksi jamur.
\end{abstract}

\section{Kata Kunci : Dermatofitosis, Wilayah kerja}

Dermatofitosis yaitu penyakit yang disebabkan oleh golongan jamur dermatofita disebut "Dermatofitosis". Golongan jamur ini dapat mencerna keratin kulit oleh karena mempunyai daya tarik kepada keratin (keratinofilik) sehingga infeksi jamur ini dapat menyerang lapisan-lapisan kulit mulai dari stratum korneum sampai dengan stratum basalis. Dermatofitosis disebabkan jamur golongan dermatofita yang terdiri dari tiga genus yaitu genus: Mikrosporon, Trikofiton dan Epidermofiton. Dari 41 spesies dermatofit yang sudah dikenal hanya 23 spesies yang dapat menyebabkan penyakit pada manusia dan 
binal

7 s

Epidermafiton (Unandar, 2004).

Dermatofitosis mempunyai sifat

keratinofilik, setiap spesies dermatofita mempunyai afinitas terhadap hospes tertentu. Dermatofita yang zoofilik terutama menyerang binatang, dan kadang-kadang menyerang manusia. Misalnya : Mikrosporon canis dan Trikofiton verukosum. Dermatofita yang geofilik adalah jamur yang hidup di tanah dan dapat menimbulkan radang pada manusia, misalnya Mikrosporon gipsium (Unandar, 2004). Penelitian ini bertujuan untuk mengetahui hubungan wilayah kerja terhadap kejadian infeksi jamur pada karyawan PT. Perkebunan Nusantara VII di Kabupaten Bengkulu Utara.

Jamur sangat erat hubungannya dengan manusia. Jamur bisa hidup dan tumbuh dimana saja, baik di udara, tanah, air, pakaian bahkan di tubuh manusia sendiri. Indonesia sebagai lahan tropis menjadi lahan subur tumbuhnya jamur khususnya jamur Tricopiton rubrum. Oleh sebab itu, penyakit-penyakit akibat jamur ini sering kali menjadi penyakit masyarakat. (Siregar, 2005).

Trichophyton rubrum menyerang jaringan kulit dan menyebabkan beberapa infeksi kulit antara lain: Tinea pedis yang berlokasi diantara sela jari- jari kaki, infeksi ini banyak terdapat pada orang yang kerap memakai sepatu, Tinea cruris yang berlokasi di lipatan paha dan Tinae unguium yang berlokasi di kuku tangan maupun kaki (Anonim, 2012).

Menurut Ratna (2006) Tinea pedis terdiri dari beberapa macam tipe klinis, dan yang paling sering ditemukan, antara lain : 1) Bentuk interdigitalis yang merupakan kelainan berupa maserasi, skuamasi serta erosi di celah-celah jari terutama jari ke-4 dan 5. Kulit terlihat putih, dapat berbentuk fisura dan sering tercium bau yang tidak enak. Lesi dapat meluas ke bawah jari dan telapak kaki; 2) Bentuk hiperkeratosis menahun yaitu terjadi penebalan kulit disertai sisik terutama pada tumit, telapak kaki, tepi kaki dan punggung kaki. Lesi dapat berupa bercak dengan skuama putih agak mengkilat, melekat, dan relative tidak telapak kaki, sering simetris dan disebut moccasin foot; 3) Bentuk vesikular subakut yaitu kelainan timbul pada daerah disekitar jarijari kemudian meluas ke punggung kaki atau telapak kaki, disertai rasa gatal yang hebat. Bila vesikel pecah akan meninggalkan skuama melingkar yang disebut koloret. Bila terjadi infeksi akan memperberat keadaan sehingga terjadi erysipelas.

Penyebab tersering Tinea kruris termasuklah Trichophyton rubrum dan Epidermophyton floccosum kadang dijumpai juga Trichophyton mentagrophytes dan Trichophyton verrucosum. Tinea kruris adalah penyakit infeksi berjangkit yang dapat ditularkan melalui pakaian atau bahan yang dipakai yang terkontaminasi, oleh autoinokulasi dari reservoir dari tangan atau kaki (tinea pedis, tinea unguium). Agen penyebab ini menghasilkan keratinases enzim yang bersifat toksin, yang membenarkan invasi ke dalam lapisan sel tanduk pada epidermis. Respon imun badan akan menghalang invasi lebih dalam. Menyebabkan rasa gatal atau sedikit panas di tempat tersebut akibat timbulnya peradangan dan iritasi. Faktor risiko infeksi awal atau kekambuhan adalah memakai pakaian ketat atau basah. Peluh yang berlebihan di kawasan tertentu. Cara penularan jamur dapat secara langsung maupun tidak langsung (Oktafani, 2009).

Working diagnosis, diagnosis ditegakkan berdasarkan anamnesis dan pemeriksaan fisik dengan melihat gambaran klinis dan lokasi terjadinya lesi serta pemeriksaan penunjang seperti yang telah disebutkan dengan menggunakan mikroskop pada sediaan yang ditetesi $\mathrm{KOH} 10-40 \%$, untuk mempercepat proses pelarutan dapat dilakukan pemanasan sediaan basah dari api kecil. Pada saat mulai keluar uap dari sediaan tersebut maka terbentuk kristal $\mathrm{KOH}$ sehingga untuk melihat elemen jamur lebih nyata ditambahkan pada sediaan $\mathrm{KOH}$ misalnya tinta parker superchroom blue black selain itu dapat juga dilakukan sediaan biakan pada medium Saboraud (ditambahkan antibiotik saja atau ditambah pula klorhek- 
simid, kedua zat tersebut diperlukan untuk menghindarkan kontaminasi bakteri maupun jamur kontaminan), punch biopsi, atau penggunaan lampu wood pada sediaan kulit yang terlihat adalah hifa sebagai dua garis sejajar terbagi oleh sekat dan bercabang maupun spora berderet pada kelainan kulit lama atau sudah diobati (Oktafani, 2009).

Different diagnosis, psoriasis penyakit yang penyebabnya autoimun, bersifat kronik dan residif, ditandai dengan adanya bercak eritema berbatas tegas dengan skuama yang kasar, berlapis-lapis dan transparan, disertai fenomena tetesan lilin, Auspitz, dan Kobner. Tempat predileksi pada skalp, perbatasan daerah tersebut dengan muka, ekstremitas ekstensor terutama siku serta lutut dan daerah lumbosakral. Kelainan kulit terdiri atas bercak eritema yang meninggi dengan skuama diatasnya. Eritema sirkumskrip dan merata, tetapi pada stadium penyembuhan sering bagian di tengah menghilang dan hanya terdapat di pinggir. Skuama berlapis-lapis, kasar dan berwarna putih, serta transparan. Besar kelainan bervariasi dapat lentikular, numular atau plakat, dapat berkonfluensi. Biasanya penderita mengeluh gatal. Psoariasis juga dapat menyebabkan kelainan kuku. Kelainan yang khas adalah kuku keruh ,tebal bagian distalnya terangkat pada lapisan tanduk dibawahnya, selain di kuku dapat juga di sendi umumnya bersifat poliartikular kemudian terjadi ankilosis dan lesi kistik subkorteks (Oktafani, 2009).

Tinea pedis terdapat di seluruh dunia sebagai dermatofitosis yang paling sering terjadi. Meningkatnya insidensi Tinea pedis mulai pada akhir abad ke-19 sehubungan dengan penyebaran Trichophyton rubrum ke Eropa dan Amerika. Hal ini dipengaruhi oleh perjalanan orang keliling dunia, pendudukan koloni oleh Inggris dan Perancis pada abad ke19 dan awal abad ke-20 dan migrasi penduduk selama perang dunia kedua. Beberapa penulis berspekulasi bahwa area endemik spesies ini bermula di Asia Tenggara (Unandar, 2004).

Tingkat prevalensi Tinea pedis secara nyata diketahui karena pasien tidak mencari nasihat medis kecuali kualitas hidup mereka dipengaruhi, karena ini bukan penyakit yang mengancam jiwa. Diperkirakan $10 \%$ dari jumlah penduduk di banyak negara menderita penyakit ini. Frekuensi Tinea pedis di Eropa dan Amerika Utara berkisar 15-30\% dan pada beberapa masyarakat tertentu lebih tinggi, misalnya buruh tambang (sampai 70\%) dan atlit. Tinea pedis lazim ditemukan pada daerah beriklim tropis dan sedang (Unandar, 2004).

Tinea pedis, Tinea cruris dan Tinea unguium lebih sering terjadi pada usia dewasa daripada anak remaja terutama pada laki-laki dan jarang pada perempuan dan anak-anak. Kemungkinan infeksi berkaitan dengan paparan ulangan dermatofita sehingga orang yang menggunakan fasilitas mandi umum seperti pancuran, kolam renang, kamar mandi lebih cenderung terinfeksi (Anonim, 2012).

Pada Trichophyton mentagrophytes, penggabungan sitoplasma tidak diikuti segera dengan penggabungan inti. $\mathrm{Hal}$ ini menyebabkan terjadinya fase pendek dikariotik. Hifa dikario-tik dilindungi dan diberi makan oleh hifa. (Siregar, 2005).

Pencegahan berupa pendidikan kepada pasien dan penjagaan kebersihan diri seperti menjaga tubuh supaya tidak lembab, mengganti pakaian lembab, jangan menggaruk-garuk tempat yang ada jamur tersebut, sebab bisa menular ketempat lain, gunakan pakaian yang dapat menyerap keringat, jangan bertukar-tukar handuk, sabun, pakaian dan tentunya rajin mandi (Oktafani, 2009).

Pengobatan dengan salep anti jamur untuk dioleskan di tempat jamur tersebut. Banyak tersedia berbagai salep anti jamur dan dijual secara bebas. Pengolesan salep sebaiknya setelah mandi, dan dalam kondisi bagian yang terinfeksi harus kering, sehingga salep dapat menempel dengan baik di kulit (Oktafani, 2009).

Lingkungan merupakan salah satu faktor penentu derajat kesehatan, di samping beberapa variabel lainnya. Senada dengan hal tersebut, menurut laporan terbaru organisasi kesehatan dunia (WHO) sebanyak $24 \%$ dari penyakit global disebabkan oleh segala jenis faktor lingkungan yang dapat dicegah. Oleh karena itu, selanjutnya dibutuhkan upaya yang lebih intensif dan serius dari banyak pihak untuk 
melakukan intervensi terhadap faktor lingkungan (Muninjaya, 2004).

Lingkungan keria merupakan tempat vang poter

Faktc

kesehatan pekerja antara lain faktor fisik, faktor kimia, dan faktor biologis. Lingkungan kerja ataupun jenis pekerjaan dapat menyebabkan penyakit akibat kerja (Ratna, 2006).

Kondisi lingkungan kerja sangat mempengaruhi kesehatan pekerjanya, seperti kondisi lingkungan kerja di PT. Perkebunan Nusantara VII pada bagian pengolahan karet yang cenderung basah sehingga karyawan banyak yang terinfeksi jamur, seharusnya karyawan menggunakan standar APD (Alat Pelindung Diri) saat bekerja seperti : helm, masker, sarung tangan, baju plastik, dan sepatu boot. Dapat disimpulkan bahwa ada hubungan antara wilayah kerja dengan kejadian infeksi jamur.

\section{BAHAN DAN CARA KERJA}

Penelitian ini merupakan jenis penelitian observasional analitik dengan desain cross sectional.' Pada penelitian ini variable independent (bebas) adalah karyawan sedangkan variabel dependent (terikat) jamur.

Penelitian ini dilakukan di PT. Perkebunan Nusantara VII dan pemeriksaan dilakukan di Laboratorium Poltekkes Kemenkes Bengkulu pada bulan Mei 2013. Populasi dalam penelitian ini adalah seluruh karyawan PT. Perkebunan Nusantara VII pada bagian pengolahan yang berjumlah 17 orang karyawan, bagian pengasapan yang berjumlah 3 orang karyawan, dan bagian sortasi yang berjumlah 9 orang karyawan. Sampel yang digunakan dalam penelitian ini menggunakan teknik total sampling dimana jumlah populasi yang berjumlah 29 orang karyawan seluruhnya dijadikan sampel penelitian.

Penelitian ini menggunakan pemeriksaan secara langsung memakai $\mathrm{KOH} 10 \%-40 \%$. Alat yang digunakan pada penelitian ini adalah : Mikroskop, kaca arloji, batang pengaduk, neraca analitik, labu ukur, beker glas, ose bulat, kaca benda, kaca penutup, kapas, bunsen, skapel, korek api, pot , pipet tetes, dan bahan yang digunakan adalah : Alkohol 70\%, larutan
$\mathrm{KOH} 10 \%-40 \%$, kerokan kulit dan kuku yang terinfeksi Tinea pedis, Tinea kruris, dan Tinea ungium. Cara keria dengan langkah sebagai

Hubungan Wilayah Kerja Terhadap Kejadian Jamur... 33

diambil pada daerah yang masih aktif; (2) Kelainan kulit dan kuku tersebut dikerok sisik kulitnya dengan menggunakan spatel yang steril; (3) Letakkan diatas objek glass dan tetesi dengan $\mathrm{KOH} 10 \%$ untuk kerokan kulit dan $\mathrm{KOH} 40 \%$ untuk kerokan kuku, kemudian tutup dengan deck glass; (4) Lewatkan pemeriksaan tersebut beberapa kali diatas nyala api; (5) Pemeriksa dibawah mikroskop, mulamula dengan pembesaran 10 kali, kemudian dengan perbesaran $40 \mathrm{kali}$; (6) Interpretasi hasil (+) Bila ditemukan hifa dan spora, dan (-) Bila tidak ditemukan hifa dan spora.

Analisis univariat dilakukan terhadap tiap variabel dari hasil penelitian. Analisis terhadap satu variabel. Biasanya dilakukan analisis untuk mengetahui : Distribusi frekuensi. Analisis Bivariat dalam penelitian menggunakan uji chisquare pada $\alpha 5 \%$. Analisis ini dilakukan dengan melihat hubungan wilayah kerja terhadap kejadian infeksi jamur pada karyawan PT. Perkebunan Nusantara VII di Kabupaten Bengkulu Utara. Hasil penelitiandikatakan signifikan bila nilai $\mathrm{P}<\alpha \quad 0,05$ maka Hipotesis ditolak. Pelaksanaan penelitian dibagi menjadi dua tahap, yaitu tahapan persiapan dan tahapan pelaksanaan. Pada tahapan persiapan meliputi kegiatan penetapan judul, survey awal, pengumpulan data, merumuskan masalah penelitian, menyiapkan instrumen penelitian, ujian proposal. Setelah itu mengurus surat izin penelitian.

Responden dalam penelitian ini berjumlah 29 orang. Pada hari rabu menemui responden. Untuk memperoleh data variabel independen responden di pisahkan berdasarkan wilayah lingkungan kerjanya yaitu karyawan bagian pengolahan, karyawan bagian pengasapan, dan karyawan bagian sortasi. Untuk variabel dependent yaitu dengan cara mengambil sampel pada responden : dengan cara kelainan pada kulit atau kuku dibersihkan dengan alkohol $70 \%$, kemudian kelainan pada kulit atau kuku tersebut dikerok sisik kulitnya menggunakan 
spatel yang steril, kerokan kulit atau kuku tersebut dimasukkan kedalam wadah sampel atau pot yang telah diberi $\mathrm{KOH} 10 \%$ untuk pemeriksaan Tinea pedis dan Tinea cruris dan 34 Jurnal Media Kesehatan, Volume 8 Nomor 1, April 2015, hlm 01-99 didapatkan sebagian besar karyawan yaitu 88,2 $\%$ terinfeksi jamur dan sebagian kecil karyawan yaitu $11,8 \%$ tidak terinfeksi jamur sedangkan bada bagian bukan pengolahan karet nilai P $(0.000)<$ dari pada $\alpha(0.05)$ sehingga dapat disimpulkan bahwa ada hubungan yang signifikan antara wilayah kerja dengan kejadian infeksi jamur.

Tabel 2. Hasil Analisa Hubungan Wilayah Kerja Terhadap Kejadian Infeksi Jamur Pada Karyawan PT.Perkebunan Nusantara VII

40\% Tinea unguium di ambil menggunakan ose bulat yang telah dipanaskan; 2) Kemudian diletakkan di atas objek glass yang steril, di tutup dengan deck glass; 3) Fiksasi di atas Bunsen; 4) Diperiksa secara mikroskop, mula-mula dengan perbesaran 10 setelah itu dilanjutkan dengan perbesaran 40. Dari hasil pemeriksaan tersebut positif bila ditemukan hifa dan spora, dan negatif bila tidak ditemukan hifa dan spora.

\section{HASIL}

Setelah data dikumpulkan kemudian data diolah secara univariat dengan menggunakan rumus distribusi frekuensi dan bivariat dengan menggunakan uji Chi-Square.

\section{Analisis Univariat}

Tabel 1. Distribusi Frekuensi Wilayah Kerja dan Kejadian Infeksi Jamur di PT. Perkebunan Nusantara VII di Kabupaten Bengkulu Utara Tahun 2013.

\begin{tabular}{lcc}
\hline \multicolumn{1}{c}{ Variabel } & Frekuensi & $\begin{array}{c}\text { Presentase } \\
(\mathbf{\%})\end{array}$ \\
\hline Wilayah Kerja & & \\
Pengolahan Karet & 17 & 58,6 \\
Bukan Pengolahan Karet & 12 & 41,4 \\
Kejadian Infeksi Jamur & & \\
Positif & 15 & 51,7 \\
Negatif & 14 & 48,3 \\
\hline
\end{tabular}

Berdasarkan tabel 1 dapat dilihat bahwa sebagian besar responden $(58,6 \%)$ bekerja di pengolahan karet, dan sebagian kecil responden $(41,4 \%)$ bekerja di bagian bukan pengolahan karet (pengasapan dan sortasi), dan bahwa sebagian besar responden $(51,7 \%)$ terinfeksi jamur, dan sebagian kecil responden $(48,3 \%)$ tidak terinfeksi jamur.

\section{Analisis Bivariat}

Berdasarkan tabel 2 dapat diketahui bahwa pada wilayah kerja di bagian pengolahan karet

\begin{tabular}{|c|c|c|c|c|c|c|c|}
\hline \multirow{3}{*}{$\begin{array}{l}\text { Variabel } \\
\text { (Wilayah } \\
\text { Kerja) }\end{array}$} & \multicolumn{4}{|c|}{ Infeksi jamur } & \multirow{3}{*}{$\mathbf{f}$} & \multirow{3}{*}{$\%$} & \multirow{3}{*}{$\mathbf{P}$} \\
\hline & \multicolumn{2}{|c|}{+} & \multicolumn{2}{|c|}{-} & & & \\
\hline & $\mathbf{f}$ & $\%$ & f & $\%$ & & & \\
\hline $\begin{array}{l}\text { Pengolahan } \\
\text { karet }\end{array}$ & 15 & 88,2 & 2 & 11,8 & 17 & 100 & \\
\hline $\begin{array}{l}\text { Bukan } \\
\text { pengolahan } \\
\text { karet }\end{array}$ & 0 & 0 & 12 & 100 & 12 & 100 & 0.000 \\
\hline
\end{tabular}

\section{PEMBAHASAN}

Dari hasil yang dilakukan analisis menunjukkan bahwa ada hubungan yang signifikan antara wilayah kerja terhadap kejadian infeksi jamur pada karyawan PT. Perkebunan Nusantara VII Kabupaten Bengkulu Utara.

Lingkungan wilayah kerja yang tidak memenuhi standar kesehatan diketahui merupakan faktor resiko timbulnya gangguan kesehatan masyarakat seperti infeksi jamur. Infeksi jamur merupakan salah satu penyakit yang erat hubungannya dengan personal hygiene dan lingkungan kerja. Seperti pada salah satu wilayah lingkungan kerja di PT. Perkebunan Nusantara VII di Kabupaten Bengkulu Utara, yaitu pada bagian pengolahan. Pada wilayah ini, karyawan berkontak langsung dengan air yang merupakan salah satu sumber penularan infeksi jamur. Air yang cenderung kotor merupakan tempat yang baik untuk pertumbuhan jamur. Tubuh para karyawan pengolahan yang terpapar air dalam waktu lama juga merupakan salah satu penyebab timbulnya infeksi jamur. Jam kerja yang relatif lama juga merupakan salah satu penyebab timbulknya infeksi. Dari 17 orang karyawan pada bagian pengolahan terdapat 2 orang karyawan tidak terinfeksi jamur dikarenakan karyawan tersebut menggunakan APD (Alat Pelindung Diri) saat bekerja sehingga tid- 
ak berkontak langsung dengan air yang merupakan sumber penularan infeksi jamur.

Pada bagian pengasapan lingkungan kerjanya cenderuno nanas sehinoga kurano mer Lely, dkk Hubungan Wilayah Kerja Terhadap Kejadian Jamur... 35

dang

janya bersih dan kering. Pada ketiga wilayah kerja tersebut juga tidak ada rotasi atau perputaran kerja bagi para karyawannya, sehingga karyawan pada bagian pengolahan lebih mudah terinfeksi jamur karena terlalu sering terpapar air dan tidak memakai APD (Alat Pelindung Diri) saat bekerja dibandingkan dengan karyawan di bagian pengasapan dan sortasi yang lingkungan kerjanya kering dan bersih.

Penelitian ini didukung oleh pernyataan Muninjaya (2004) yang menyatakan bahwa lingkungan merupakan salah satu faktor penentu derajat kesehatan, di samping beberapa variabel lainnya. Senada dengan hal tersebut, menurut laporan terbaru organisasi kesehatan dunia (WHO) sebanyak $24 \%$ dari penyakit global disebabkan oleh segala jenis faktor lingkungan yang dapat dicegah. Oleh karena itu, selanjutnya dibutuhkan upaya yang lebih intensif dan serius dari banyak pihak untuk melakukan intervensi terhadap faktor lingkungan.

Lingkungan kerja merupakan tempat yang potensial mempengaruhi kesehatan pekerja. Faktor-faktor yang dapat mempengaruhi kesehatan pekerja antara lain faktor fisik, faktor kimia, dan faktor biologis. Faktor fisik seperti halnya karyawan pada bagian pengolahan di

\section{DAFTAR RUJUKAN}

Anneahira, 2009. Panu, penyakit kulit yang tidak berbahaya. Diakses dari http//www.Anneahira.com

Budimulja.U, 2004. Dermatomikosis Superfisialis. Jakarta: FKUI.

Bramono. K, 2004. Pemaparan Tentang Jamur. Jakarta.

Brown. R, 2005. Dermatologi. Erlangga. Jakarta.

Cipta, 2008. Kebutuhan Personal Hygiene. Diakses dari www.serbaserbikesehatan.com

Dian. R, 2006. Faktor-fakto Yang Berhubungan Denga Kejadian Tinea pedis Pada Pemulung di TPA Jatibarang Semarang. Semarang.

Gandahusada. S, 2003. Parasitologi Kedokteran Edisi Ketiga. FKUI. Jakarta.

Graham. R, 2005. Dermatologi. Jakarta: Erlangga.

Harahap. M, 2000. Ilmu Penyakit Kulit. Jakarta: Hipokrates.
PT.Perkebunan Nusantara VII yang berkontak langsung dengan air yang merupakan salah satu sumber penularan infeksi jamur. Lingkungan keria ataunun ienis nekeriaan danat menvehahinfeksi jamur khưusnya Tinea pedis secara tidak langsung dapat melalui tanaman, kayu yang dihinggapi jamur, barang-barang atau pakaian, debu atau tanah, dan air yang terkontaminasi spora jamur. Hal ini juga sesuai dengan teori Hainer bahwa penularan jamur dapat terjadi secara langsung maupun tidak langsung.

\section{KESIMPULAN}

Berdasarkan penelitian dan pembahasan Hubungan Wilayah Kerja Terhadap Kejadian Infeksi Jamur Pada Karyawan PT.Perkebunan Nusantara VII di Kabupaten Bengkulu Utara Tahun 2013 dapat disimpulkan bahwa ada hubungan yang signifikan antara wilayah kerja terhadap kejadian infeksi jamur di PT. Perkebunan Nusantara VII di Kabupaten Bengkulu Utara tahun 2013dan sebanyak 58,6 \% responden bekerja di bagian pengolahan karet dan 51,7 \% responden terinfeksi jamur.

Bagi PT. Perkebunan NusantaraVII diharapkan pihak PT. Perkebunan Nusantara VII lebih sering memberikan informasi dan saran pada karyawan untuk lebih memperhatikan penggunaan APD (Alat Pelindung Diri) dalam bekerja agar tidak terinfeksi jamur.

Ichan, 2009. Dermatofitosis "penyakit kulit”. Diakses dari http//www.IcHan-RiZkAn. Com. Html.

Laksmintari, 2007. Pengobatan dan Pencegahan Penyakit Kulit Dan Kelamin. PT.Sunda Kelapa Pustaka. Jakarta.

Muninjaya. A, 2004. Manajemen Kesehatan Edisi Ke Dua. ECG. Jakarta.

Murti. B, 2003. Prinsip dan Metode Riset Epidemiologi, Ed. Kedua, Gajah Mada University press, Yogyakarta.

Nadesul. H, 2004. Infeksi Jamur Kulit. Diakses dari www.depkes.co.id.

Notoatmodjo, 2007. Metode Penelitian Kesehatan. Rineka cipta, Jakarta.

Oktafani, 2009. Tinea Kruris. Jakarta: FKUI. 
Perdoski, 2001. Dermatofitosis Superfisialis. Jakarta: FKUI.

Ratna. D, 2006. Faktor-fakto Yang Berhubungan Denga Kejadian Tinea pedis Pada Pemulung di TPA Jatibarang Semarang. Semarang.

Robin, 2005. Patologis Penyakit Kulit. EGC.Jakarta.
Siregar, 2005. Penyakit Jamur Kulit. Palembang: Universitas Kedokteran Palembang.

Sobera. J, 2003. Dermatology volume 1. US: Mosby Elsevier.

Subakir, 2005. Mikologi kedokteran. Semarang.

Unandar, 2004. Ilmu Penyakit Kulit Dan Kelamin. Jakarta: FKUI. 